\title{
THE ENTREPRENEUR IN ECONOMIC DYNAMISM: A COMPARATIVE ANALYSIS PROPOSAL
}

\author{
Anca Elena LUNGU ${ }^{a *}$ \\ a) Alexandru Ioan Cuza University, Faculty of Economics and Business \\ Administration, Iași, Romania
}

Please cite this article as:

Article History:

Lungu, A.E., 2020. The entrepreneur in economic Received: 20 October 2019 dynamism: A comparative analysis proposal. Review Accepted: 10 December 2019 of Economic Studies and Research Virgil Madgearu, 13(1), pp.45-60.

doi: 10.24193/RVM.2020.13.51.

\begin{abstract}
The entrepreneurial actions that individuals take are neither an equilibrium sequence, nor a equilibrium tendency, but an entire market or discovery process. Therefore, dynamism is the result thereof. The market process per se is not bowed to a static nature, given that every individual's decisions have an influence on the social order through action and reaction. Change is the only constant in this whole social mechanism, and individuals' adaptability in the marks of resource allocation and result distribution leads not to an economical efficiency (which is a static concept), but a dynamic one, where entrepreneurs and their activities can be quantified through monetary calculation with the aim of gaining profit. The main objective of this article is to enhance the idea of dynamic efficiency in a space of entrepreneurial activity. Methodologically, we have used quantitative analysis techniques in order to identify the relationship between entrepreneurs and economic development.
\end{abstract}

Key words: entrepreneurship; dynamic efficiency; market; economic development JEL Classification: $L 26$; $B O O$

(C) 2020 Alma Mater Publishing House. All rights reserved.

* Corresponding author. E-mail address: ancalunguo1@gmail.com. 


\section{References:}

1. De Soto, J., 2011. Teoria eficienței dinamice. Iași: Editura Universității Alexandru Ioan Cuza.

2. Gove, P., 1981. Webster's Third New International Dictionary. 3rd ed. Chicago: Encyclopedia Britannica.

3. Hayek, F., 1988. The Fatal Conceit: The Errors of Socialism. Londra: Routledge.

4. Hayek, F., 2014. Utilizarea cunoașterii în societate. In: Individualism și ordine economică. Iași: Editura Universității Alexandru Ioan Cuza, Iași, pp.81-93.

5. Kirzner, I., 1997. How Markets Work: Disequilibrium, Entrepreneurship and Discovery. London: Published by The Institute of Economic Affairs.

6. Mises, L., 1998. Human Action. A Treatise on Economics (The Scholar's Edition). Auburn, Alabama: Ludwig von Mises Institute.

7. Mises, L., 2018. Acțiunea Umană. București: Editura Institutului Ludwig von Misws România.

8. North, D.C., 1990. Institutions, Institutional Change, and Economic Performance. Cambridge: Cambridge University Press.

9. Rothbard, M., 1997. The Myth of Efficiency. In: The Logic of Action One: Method, Money, and the Austrian School. Cheltenham: Edward Elgar, pp.266-273.

10. Schumpeter, J., 1934. The theory of Economic Development. An Inquiry into Profits, Capital, Credit, Interest and the Business Cycle. London: Transcation Publishers. 